\title{
Debate
}

\section{Infant and child growth and health: standards, principles, practice}

John Waterlow, who celebrated his 90th birthday in June last year, is one of the most influential nutrition scientists of all time. I also know from family experience ${ }^{1}$ and peer testimony $^{2}$ that he is a generous mentor and inspiring leader. The $1985 \mathrm{FAO} / \mathrm{WHO} / \mathrm{UNU}$ report specifying human energy and protein requirements ${ }^{3}$, the product of a consultation which he chaired, is (remarkably) ${ }^{4}$ still current in the case of protein, and is a masterpiece of elegant and lucid argument.

As professor at the London School of Hygiene and Tropical Medicine between 1970 and 1981, he built up his department 'on four legs: metabolism; clinical nutrition; public health nutrition; and nutrition policy'5. To his great disappointment, the basic and applied parts of the department were cleaved after his retirement ${ }^{6}$. Recently he had kind words to say about the three-dimensional biological, social and environmental new nutrition science $^{5}$. So I respond to his letter ${ }^{7}$ on past, present and future infant and child growth standards with deep respect.

His attitude to science is encapsulated in the final sentence of the 1985 report, surely written by him. 'If the present judgements are thought to be inappropriate, then it is up to the user, or the community of users, to offer more appropriate judgements. No longer can we bypass the question "Requirements for what?". This contribution addresses his courteous challenge.

\section{The formula for growth curves}

In his letter commenting on my views on infant and young child growth and health, he says that I 'seem not to appreciate the profound difference that the NCHS reference made to our knowledge of child growth throughout the world'. I do have some idea of the impact of these standards, not just in study and teaching, but also in practice. As I have seen in Brazil, and as anybody can see in any country, the growth curves designed to gauge infant and child health - still used by governments, children's hospitals and clinics in remote rural areas follow UN standards derived from datasets collected from observations made before and between 1960 and 1975 mostly of middle-class infants and young children living in Ohio and elsewhere in the USA, fed now-obsolete veryhigh-protein formula based on cow's milk, compiled by the US National Center for Health Statistics ${ }^{8}$.

Why did US formula-fed children become the global model for child growth and health? The immediate reason is that the NCHS standards were endorsed by a UN expert group chaired by John Waterlow ${ }^{9}$, were accepted in 1978 within the UN system ${ }^{10}$, were again endorsed by the consultation convened in 1981 also chaired by John Waterlow and thus were a basis for the 1985 WHO/FAO/ UNU report ${ }^{3}$, and were then formally accepted by UN member states, and so became the keystone of paediatric practice everywhere.

In his letter John Waterlow mentions that datasets available at the time from The Netherlands showed similar growth curves to those from the US NCHS. This is not surprising: The Netherlands was and is about the top nation per head for cow's milk production and consumption.

Science is not driven by data; like all other human activity, it is driven by beliefs. What John Waterlow modestly seems not to appreciate, is the impact his work continues to have. From the 1950s to and beyond the 1980s, it was almost universally accepted that the dominant paediatric public health emergency in the world was undernutrition, identified first as protein deficiency and later as protein-energy deficiency. This belief, now known to be mistaken - for nutritional deficiency usually is not just of energy and/or specific nutrients, whatever the proponents of quasi-pharmacological interventions may say - drove the research of nutrition scientists and the work done by the relevant UN agencies. It also fuelled the infant formula and powdered milk industries, because cow's milk is three times higher in protein than human breastmilk, and artificial formulas then and now are also higher in protein than breastmilk.

Protein promotes growth, and adoption of the US NCHS standards as the universal norm, their promulgation throughout the world, and a human race therefore grown up bigger, taller and heavier, is one of John Waterlow's legacies to world health. In a real sense, many of us are his children, personally as well as professionally.

\section{Emergence of the human humvee}

Is this legacy a golden bowl or a poisoned chalice? The evidence points both ways. The use of statistical methods to generate such loaded words as 'stunting' and 'wasting' is obviously troublesome. Indeed, the 1985 report acknowledges that 'cardiorespiratory function, physical performance, and muscular strength were found to be significantly better in stunted Tunisian children than in children from 
affluent families, whose growth was closer to the standard in developed countries. Similarly, Indian children from poor families performed better in physical fitness tests than their counterparts from more prosperous families, in spite of their smaller size and lower habitual energy intakes'. And furthermore: 'Nor do the effects of small stature necessarily carry penalties in adult life except for tasks requiring a particular body build and strength'3. Voltaire would be pleased to know this.

This said, the identification of low birth weight as pathogenic in itself, and also a predictor of physical and mental disease and disability in childhood and adult life, has made a vital contribution to world health. Many millions of people now alive and well surely owe their lives and health to the teaching and practice of which John Waterlow remains a leader.

On the other hand, as John Waterlow himself as chair of another consultation in $1976^{11}$ observed, obesity is a public health problem. Thirty years later, rates of weight gain, overweight and obesity have rocketed, and childhood obesity, early-life diabetes and their consequences may already be uncontrollable pandemics ${ }^{12,13}$. Paediatric principles, teaching and practice since the 1970s are one reason for this disaster. The feeding of infants and children with artificial formula and then with energy-dense fatty, sugary diets causes unnatural weight gain, overweight and obesity, which tracks into adult life. These ill-effects are made worse when the infant is born small and light, and whose 'failure to thrive' and 'need to catch up' with the NCHS standards based on formula feeding, has been and still is treated by replacement of breastfeeding by formula - doubly calamitous when water supplies are unsafe and then with energy-dense foods and drinks.

So was it a good idea to model universal child health on the standards of formula-fed children in the USA? Those who say no, have a compelling case. Humans are evolved with breastmilk, uniquely low in protein. And the idea that the USA is the best model for universal health is obviously troublesome, as anybody who walks down a street in Shanghai, London, Mexico City, Moscow or Rio de Janeiro can see. The NCHS standards have bred human humvees.

\section{Humans are evolved to grow slowly}

Until recently the conventional wisdom of the dominant group of nutrition scientists concerned with public health, such as John Waterlow throughout his distinguished career, has been that accelerated growth means improved health; and that almost without restraint, the bigger the better. As I see it, this notion has been driven not by considerations of public health, but from a general belief in technological, economic and other material growth and expansion. This ideology governed the thinking of the great imperial powers between the first period of industrialisation until the emergence of more egalitarian societies influenced by the thinking above all of
John Maynard Keynes, and now has re-emerged in a new form as the driving force of the one great power and its allies ${ }^{14}$.

Be this as it may, Homo sapiens has evolved and is adapted to grow uniquely slowly because of the size of the human brain. A first line of evidence to support this view is the protein content of breastmilk. It can be argued cogently that humans are evolved to wear out and die as soon as there is no selective advantage in being alive, which is to say around their early 40 s after their children have become adult; that only a few elders have been needed to live until and beyond three score years and ten; and that industrial food systems are what keeps us going into middle and old age ${ }^{15}$. But I doubt that anybody would celebrate a world in which over a billion people are obese.

In his letter John Waterlow says 'It was probably inevitable, though not intended, that this reference would be used to assess the growth of individual children'. The idea that reference values are not normative is an obvious contradiction in terms. This can be seen in another context by looking at nutrition labels of any processed foodstuff, which in Brazil for example include reference values for saturated fat and salt. Concerned individual purchasers who don't realise that reference values are not values, may get out their pocket calculator and make sure they achieve the value for saturated fat every day. Likewise, of course when governments promulgate UN standards for child growth, these are used not just in the compilation of population standards, but by health professionals on children. As a dedicated paediatric physician, John Waterlow has very extensive experience working in the field'. He does not need to be told to get real.

For the future these issues are resolved, with the adoption of the new UN growth standards based on exclusively breastfed children in Ghana, India, Oman, Norway and Brazil, as well as the USA $^{16}$. These will eventually find their way into rural clinics in Africa, Asia and Latin America. But the US NCHS growth standards are still being used to breed unnaturally large children who often grow into obese adults, and so will be more than a memory for a long time.

\section{The issue of funding}

All this relates to the issue of sources of funding for scientific research. Nutrition science has almost always been grossly underfunded, and in the last decades governments have gradually pushed research teams to accept money from industry. Naturally, industry funds research in order to protect its interests: directly by finding scientists whose views are harmonious with the nutritional composition of their more profitable products, indirectly by setting up foundations and institutes often with charitable status with the aim of making friends in the scientific community and influencing UN agencies, 
national governments, civil society organisations and the media.

There is a natural tendency for scientists to accept and seek funding from sources they see as beneficial to their work. Currently researchers are relaxed about being funded by the vegetables and fruits industries - not that there are rich pickings there. Since the days when highprotein diets were thought to be a solution to infant and young child mortality and morbidity, and that 'growth potential should be fully expressed', scientists have worked closely with the meat, milk and dairy industries and their representative organisations, and infant formula manufacturers have become generous supporters of research science and also of food aid programmes. This is not entirely for altruistic reasons: once mothers are induced to abandon breastfeeding, they become customers for infant formula. This continues.

May I ask that anybody who joins in this debate declares any past or present funding from the meat, milk, dairy products and infant formula industries, or from any entity originally or currently funded by the infant formula industry?

Geoffrey Cannon

Juiz de Fora, Minas Gerais, Brazil

Email: GeoffreyCannon@aol.com

\section{References}

1 Cannon G. Science [Chapter 4]. The Good Fight. The Life and Work of Caroline Walker. London: Ebury, 1989.

2 Shetty P, ed. Nutritional Metabolism and Malnutrition. Festschrift for John Conrad Waterlow. London: SmithGordon, 2000
3 WHO. Energy and Protein Requirements. Report of a Joint FAO/WHO/UNU Expert Consultation. WHO Technical Report Series No. 724. Geneva: WHO, 1985.

4 Millward J. FAO/WHO/UN protein requirements. Identifying recommended dietary allowances for protein: a continuing saga. Nutrition Society Gazette 2005; 29: 1-2.

5 Waterlow J. Introduction to reprint of the Sixth Boyd Orr Memorial Lecture. Public Health Nutrition 2006; 9(3): 283.

6 Waterlow J. Some reminiscences [Chapter 2]. Nutritional Metabolism and Malnutrition. Festschrift for John Conrad Waterlow. London: Smith-Gordon, 2000.

7 Waterlow J. Child growth standards [Letter to the Editor]. Public Health Nutrition 2006; 9(5): 662.

8 National Center for Health Statistics. Growth Curves for Children Birth-18 years, United States. DHEW Publication 78-1650. Washington, DC: Government Printing Office, 1977.

9 Waterlow J, Buzina R, Keller W, Lane J, Nichaman M, Tanner J. The presentation and use of height and weight data for comparing nutritional status of groups of children under the age of 10 years. Bulletin of the World Health Organization 1977; 55(4): 489-98.

10 WHO. A Growth Chart for International Use in Maternal and Child Health Care. Guidelines for Primary Health Care Personnel. Geneva: WHO, 1978.

11 Department of Health and Social Security/Medical Research Council. Research on Obesity. London: HMSO, 1976.

12 WHO. Obesity: Preventing and Managing the Global Epidemic. Report of a WHO Consultation. WHO Technical Report Series No. 894. Geneva: WHO, 2000.

13 House of Commons Health Committee. Obesity. London: HMSO, 2004.

14 Cannon G. Fast growth, and animal protein [Chapter 3]. The Fate of Nations. Food and Nutrition Policy in the New World. London: Caroline Walker Trust, 2003.

15 Fogel W. The Escape from Hunger and Premature Death, 1700-2100. Europe, America and the Third World. Cambridge: University Press, 2004.

16 de Onis M, Garza C, Victora C, Bhan M, Norum K. The WHO Multicentre Growth Reference Study: rationale, planning and implementation. Food and Nutrition Bulletin 2004; 25(1S): 3-84. 